the relatively insensitive methods then available, was unable to demonstrate any urobilinogen in urine excreted during the night. Salen (1924) confirmed that the highest output was between noon and 4 p.m. and warned against drawing any conclusions from arbitrary urine samples rather than 24-hour collections. Quodbach (1936) obtained similar results, and found that the rhythm was unaffected by taking the main meal at 2 a.m. or by feeding every two hours throughout the day by a gastric tube. He considered that the regular variations in urinary urobilinogen were due to an "endogenous liver rhythm." In addition, there is up to $300 \%$ variation in urinary urobilinogen from day to day (Royer, 1943).

The present results show that the diurnal variation in urinary urobilinogen is due to at least two factors: variation in renal clearance from diurnal changes in urinary $\mathrm{pH}$, and alterations in plasma urobilinogen concentration. A high rate of excretion can occur only when there is both a high plasma concentration and a relatively high urinary $\mathrm{pH}$. This combination usually occurs between noon and 4 p.m., when plasma levels are generally above $6 \mu \mathrm{g} . / 100 \mathrm{ml}$. and the urine is a maximum $\mathrm{pH}$ value in relation to diurnal change.

These results are of practical importance in the interpretation of urinary urobilinogen output. Determination of the 24-hour output is of little value unless the average urinary $\mathrm{pH}$ is known. Urobilinogen is much more stable in alkaline than in acid conditions, and storage for a whole day without alkalinization is likely to give too low a result. Probably the best specimen for analysis would be a two-hour or four-hour specimen collected between noon and 4 p.m. The urinary $p H$ should be determined immediately, and if there is any delay in analysis the specimen should be alkalinized before storage. Normal values can be given only if corrections are made for urinary $\mathrm{pH}$ (Fig. 1).

\section{Summary}

Urobilinogen output and clearance are correlated with urinary $\mathrm{pH}$, the values being higher in alkaline urines and lower in acid specimens. The ratio between the urobilinogen and endogenous creatinine clearance averages 0.03 at urine $p \mathrm{H} 5$ and 0.22 at urine $p H$ 8. Normal plasma urobilinogen is estimated as $5.3 \pm 3.2 \mu \mathrm{g} . / 100 \mathrm{ml}$. Urobilinogen is about $80 \%$ bound to plasma protein, and in one subject the urobilinogen clearance was significantly reduced by probenecid. Reasons are advanced for a triple mechanism of urobilinogen excretion by the kidney-that is, glomerular filtration, proximal tubular secretion, and distal tubular $\mathrm{pH}$-dependent back-diffusion. Urobilinogen is shown to resemble other lipoid-soluble organic acids in these respects and to obey the theoretical laws of excretion by $\mathrm{pH}$-dependent diffusion.

Determination of urinary urobilinogen as an index of haemolytic states or of hepatic dysfunction is unreliable unless corrections are made for variation in urinary $\mathrm{pH}$.

\section{REFERENCES}

Clarke, E., Evans, B. M., MacIntyre, I., and Milne, M. D. (1955). Clin. Sci., 14, 421.

Grimm, F. (1893). Arch. path. Anat., 132, 246.

Gustafsson, B. E, and Lanke, L. S. (1960). F. exp. Med., 112, 975.

Henry, R. J., Sobel, C., and Kim, J. (1957). Amer. f. clin. Path., 28, 152 Jaffé, M. (1868). Zbl. med. Wiss., 6, 241.

(1869). Ibid., 7, 177.

. Accame, E., Perez, V., and Royer, M. (1963). Medicina (B. Aires), 23, 239. Macpherson, C. R., Milne, M. D., and Evans, B. M. (1955). Brit. 7.

Pharmacol., 10, 484,
Milne, M. D., Crawford, M. A., Girao, C. B., and Loughridge, L. (1960). Clin. Sci., 19, 165.

- Scribner, B. H., and Crawford, M. A. (1958). Amer. F. Med., 24, 709.

Quodbach, K. (1936). Cited by T. K. With, Biology of Bile Pigments. Arne Frost-Hansen, Copenhagen. 1954.

Royer, M. (1943). La urobilina en el estado normal y patológico, 2nd ed.

El Ateneo, Buenos Aires.

14, 94 .

and Solari, A. V. (1941). Rev. Soc. argent. Biol., 17, 329.

Saillet (1897). Rev. Med. (Paris), 17, 109

Salén, E. B. (1924). Acta med. scand., 60, 291.

Sborov, V. M., Jay, A. R., and Watson, C. J. (1951). F. Lab. clin. Med., 37, 52.

Watson, C. J. (1936). Amer. F. clin. Path., 6, 458. (1937). Arch. intern. Med., 59, 196. (1963). \%. clin. Path., 16, 1.

Lowry, P., Collins, S., Graham, A., and Ziegler, N. R. (1954).

Trans. Ass. Amer. Phycns, 67, 242. H. O. (1953). f. biol. Chem., 200, 697

Weiner, I. M., and Mudge, G. H. (1964). Amer. F. Med., 36, 743.

\title{
Outbreaks of Conjunctivitis due to the Newcastle Disease Virus Among Workers in Chicken-broiler Factories
}

\author{
D. G. TROTT,* M.B., CH.B., D.P.H., D.I.H. ; R. PILSWORTH, $†$ M.D., DIP.BACT.
}

Brit. med. F., 1965, 2, 1514-1517

Newcastle disease, a disease of world-wide distribution in fowls, was described originally by Doyle in 1927 as a viral pneumoencephalitis. Burnet (1943) reported the first proved human infection as an acute follicular conjunctivitis without keratitis in a laboratory worker who became infected by the accidental introduction of infected material into the conjunctival sac. Subsequently eight cases of human infection in which the virus was isolated have been reported (Anderson, 1946 ; Freymann and Bang, 1949 ; Ingalls and Mahoney, 1949 ; Gustafson and Moses, 1951 ; Hunter, Keeney, and Sigel, 1951).

Only two cases reported by Ingalls and Mahoney (1949) occurred naturally-one in a broiler-plant operative and the

* H.M. Medical Inspector of Factories, Eastern and Southern Division. † Public Health Laboratory, Chelmsford. other in a veterinary student. 'Yatom (1946) reported an outbreak of 17 cases of conjunctivitis among kitchen workers handling poultry at the Agricultural School at Mikyeh, Israel, where an outbreak had recently occurred in fowls; and Nelson et al. (1952) reported 40 cases of conjunctivitis occurring in a produce plant where poultry were eviscerated, processed, and canned.

This paper describes outbreaks of conjunctivitis at three different broiler factories owned by the same company occurring between December 1960 and December 1963. It is interesting to note that, though the Newcastle disease virus was suspected to be the causal agent from the very first outbreak in December 1960, repeated inquiry failed to discover fowl pest or signs of the disease at any of the farms supplying the 
chickens before the final outbreak at Factory B in January 1964.

\section{Chicken-broiler Industry}

The chicken-broiler industry is one which has grown rapidly in recent years, and, like others associated with highly specialized food production, this trend is likely to continue.

The chickens are raised either on farms belonging to the company or on farms having a contract to supply, so that the respective factory has continuous up-to-date knowledge both of conditions existing at the farm and of the health of the chickens produced. All chickens now coming to the factory will have been vaccinated against fowl pest. Besides this, Newcastle disease or fowl pest is notifiable to the Ministry of Agriculture and Fisheries, and where fowl pest is present at a farm only certain chickens under special licence are allowed to be sent to the broiler factory.

The chickens are brought to the factory in crates (at Factory A 40,000 a day), stunned by an electric current of 500 volts, and their throats cut. At this stage they enter the processing plant proper, which is highly organized on a modern conveyerline technique. The chickens are first dipped into hot water in order to facilitate the next stage, plucking, which is carried out by mechanical beaters. 'In the eviscerating section head, neck, feet, and viscera are removed at various points by operatives along a continuous moving overhead conveyer. The birds are then spin-chilled prior to entering the trussing section, where weighing, tying, trussing, and packing into polyethylene bags takes place. The chickens are then put into cold storage until distribution. The average time taken to process a chicken from stunning to packaging is 40 minutes.

The hands and arms of the workers, as might be expected from the nature of the work and the speed of processing, become soiled with material from the carcasses and viscera of the chickens. Of necessity a great deal of water, which contains a small amount of chlorine, is used both to facilitate the work and to ensure a high standard of cleanliness in both plant and factory. The use of large quantities of water increases the likelihood of splashing parts of the body with contaminated material. Adequate modern facilities for washing are provided.

\section{Description of Outbreaks}

The first outbreak of conjunctivitis occurred at Factory A in December 1960. Table I shows the number of cases occurring at Factory $\mathrm{A}$ at this time and subsequently up to the last outbreak in 1963.

TABLE I.-Date of Occurrence and Number of Cases at Factory A

\begin{tabular}{|c|c|c|c|c|}
\hline \multicolumn{2}{|l|}{$\begin{array}{c}\text { Date of } \\
\text { Commencement }\end{array}$} & $\begin{array}{l}\text { No. of Cases } \\
\text { Factory A }\end{array}$ & $\begin{array}{c}\text { Date of } \\
\text { Commencement }\end{array}$ & $\begin{array}{c}\text { No. of Cases } \\
\text { Factory A }\end{array}$ \\
\hline \multirow[t]{2}{*}{$\begin{array}{l}\text { December, } 1960 \\
\text { January, 1961 } \\
\text { April, 1962 } \quad . \\
\text { May, 1962 } \quad \ldots \\
\text { July, 1962 } \quad .\end{array}$} & \multirow[t]{2}{*}{$\begin{array}{l}\ldots \\
\because \\
\cdots\end{array}$} & \multirow[t]{2}{*}{$\begin{array}{l}39 \\
61 \\
61 \\
5 \\
42\end{array}$} & \multirow[t]{2}{*}{$\begin{array}{lc}\text { August/November, } & 1962 \\
\text { February, } 1963 & \ldots \\
\text { March, 1963 } & \ldots \\
\text { December, } 1963 & \ldots\end{array}$} & $\begin{array}{r}9 \\
6 \\
8 \\
57\end{array}$ \\
\hline & & & & 288 \\
\hline
\end{tabular}

In February 1963 there was an outbreak of 21 cases at Factory C, and in December 1963 cases for the first time (23) occurred at Factory B. Though the three factories are situated many miles distant from each other, on occasions a collection of chickens is made from the same supply farm either on the same day or within a day or two. Thus the outbreaks in February 1963 at Factories A and C were most likely associated with the collection of chickens infected with the Newcastle disease virus, but not showing evidence of the disease, from the same farm at this time.

All epidemics followed a similar pattern. The outbreaks were explosive in character, and, as is shown in Table I, occurred at different seasons of the year. The conjunctivitis was often unilateral ( $40 \%$ of the cases) and was never accompanied by respiratory symptoms and rarely by constitutional illness. There was little photophobia, and pre-auricular adenitis was usually slight.

In some cases symptoms of irritation of the eye began on a Friday evening after the patient had left work, but in most cases symptoms were first noted on Saturday evening, followed by a sticky eye on wakening on Sunday morning. There are well-equipped small ambulance-rooms at Factories $\mathrm{A}$ and $\mathrm{B}$ under the charge of a State-registered nurse, and in most cases, including those which developed later on a Sunday, the patient reported to the ambulance-room for treatment the following Monday. The highest rate of attendance at the ambulanceroom was thus on Mondays and Tuesdays, with a gradual falling off in numbers during the ensuing week.

The appearance of the affected eyes varied from that associated with a simple allergic conjunctivitis to a full-blown mucopurulent conjunctivitis. In many cases the bulbar conjunctiva and fornices were swollen and oedematous, and most patients complained of a feeling of heat and grittiness as of a foreign body in the eye. Treatment with antihistamine eye-drops gave rapid and continued relief from the irritation.

It was unusual to obtain a history of conjunctivitis occurring in relatives of the affected workers except where the relatives also worked at one of the broiler factories, but on two occasions it did appear that infection had been transmitted from the patient to her children. The average length of time from onset of symptoms to full recovery was three and a half days. Though we felt that the wearing of spectacles gave some measure of protection, we were unable to show this statistically. Again, though cases occurred in all sections of the various departments of the factories, the highest incidence was in those sections associated with the actual handling of the bird-that is, grading and trussing-rather than with an operation carried out while the bird passed the operative on the conveyer lines. This is demonstrated in Table II.

Table II.-Showing Distribution of Cases by Department During Outbreak at Factory B, December 1963

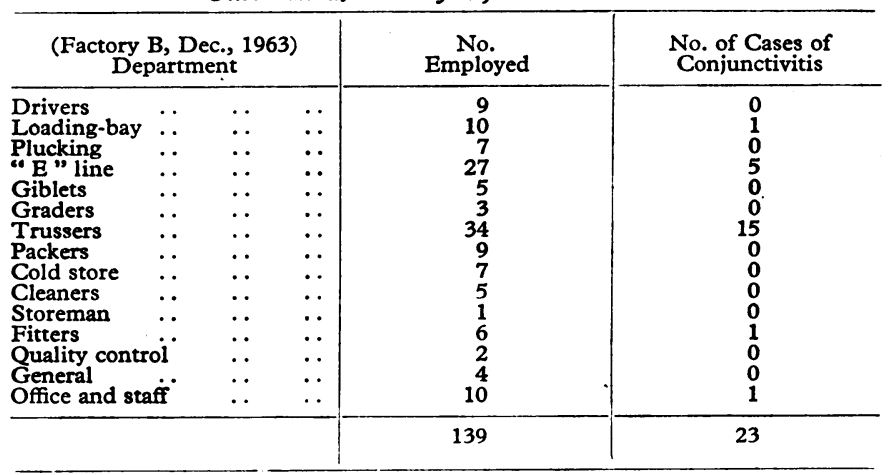

The history of water droplets entering the eye was common among the operatives, but, as pointed out above, this might be expected from the very nature of the work.

Several unsuccessful attempts were made to identify an infecting agent during the outbreaks at Factory $A$ and the February outbreak at Factory $C$ in 1963. During this period repeated inquiries were made at the farms supplying Factories $\mathrm{A}$ and $\mathrm{C}$ for the possible occurrence of fowl pest. These inquiries, however, proved negative on each occasion, and all poultry coming into the factories appeared to be healthy.

In December 1963, when the outbreak of conjunctivitis occurred at Factory B, one of us (R. P.) was successful in isolating Newcastle disease virus from a number of cases. During our initial investigation of this latter outbreak we were unable to obtain evidence of fowl pest at any of the supply farms. In late December, however, fowl pest did occur at one 
of the supply farms-that is, 24 December 1963. Arrangements had been made at this time for receiving a certain number of chickens from this farm under licence, and collections were made on 1, 2, and 3 January 1964. On 3 January the first cases of a further similar small outbreak of conjunctivitis occurred at this factory, and again Newcastle disease virus was isolated.

\section{Isolation of Newcastle Disease Virus}

Specimens.-These took the form of washings from infected conjunctival sacs. The patient sat in a chair and tilted the head backwards and slightly away from the affected side, so that when about $0.5 \mathrm{ml}$. of physiological saline was introduced on to the conjunctival surface it was retained. The paitient blinked once or twice, and as much saline as possible was recovered by means of a Pasteur pipette. The washings were mixed at once with about $0.5 \mathrm{ml}$. of nutrient broth in a small screwcapped bottle. Specimens reached the laboratory within one hour of collection and were held at $4^{\circ} \mathrm{C}$. for a few days until eggs were available.

Materials and Methods.-These are described in detail elsewhere (Pilsworth and Wall, 1964). Fertile eggs that had been incubated for 10 days were inoculated by the allantoic route, a mixture of conjunctival washings and broth untreated and without antibiotics being used. For each specimen $0.25 \mathrm{ml}$. of inoculum was used and only one egg. After incubation for three days the eggs were chilled for three to four hours and the allantoic fluid was harvested. The presence of virus in the fluid was detected by its ability to cause agglutination of human group $\mathrm{O}$ red cells. The haemagglutinating capacity of each specimen of allantoic fluid was titrated, and those having a titre of less than 1 in 64 were passed through another fertile egg; this procedure always increased the titre satisfactorily. When a titre of 1 in 64 or more had been obtained, the virus was identified by means of a haemagglutination-inhibition test, with the use of Newcastle disease virus fowl serum absorbed with human group $\mathrm{O}$ cells. This serum was kindly given by the Poultry Virus Division of the Ministry of Agriculture Laboratory at Weybridge. All allantoic fluids showing haemagglutination in the preliminary tests were prevented from agglutinating red cells by a 1 in 1,280 dilution of the absorbed Newcastle disease virus serum. Fluids treated with influenza A antiserum showed no similar inhibition of haemagglutination.

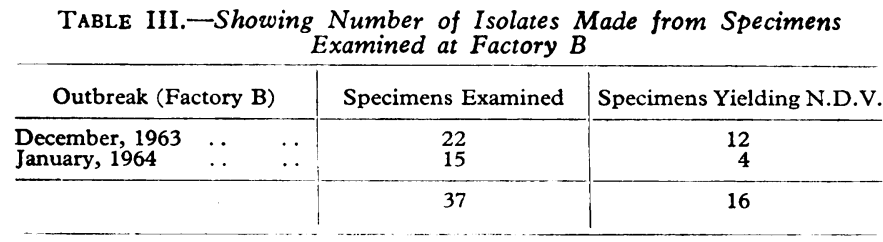

Results.-Altogether 16 isolates of Newcastle disease virus were made from 37 specimens examined during the two outbreaks. Twelve isolates were from 22 specimens examined from the December 1963 outbreak and four from 15 specimens examined during the later outbreaks in January 1964.

\section{Discussion}

Probably one of the most interesting aspects of the investigation of these outbreaks of conjunctivitis is that though the Newcastle virus was suspected from the very first cases reported to us in December 1960, we were unable to establish this as the causal agent until December 1963. In view of the explosive character of the outbreaks at the factory-that is, 39 cases in December 1960 and 61 cases in January 1961-it was felt that if an infective agent was the causal factor, then it was reasonable to expect (a) an outbreak of fowl pest at one of the supply farms, or (b) cases of conjunctivitis among farm operatives. Neither of these events occurred.

At the time of the outbreaks of conjunctivitis in Factory A in 1960 it was reported that the water used for cleansing the chickens contained over 10 p.p.m. of chlorine gas, and at times could well be in excess of this figure. Thus for a short time, in the absence of a demonstrable infecting agent, it was thought that excess chlorine in the cleansing water might be the cause of the conjunctivitis. At this stage, as later, we formed the opinion that, for any given department, the greater the likelihood of water droplets entering the eye the higher the incidence of cases on that particular process. At our suggestion the management reduced the chlorine content to 3 p.p.m. and maintained this level daily ; but, as will have been noted, further outbreaks occurred at later dates.

All epidemics followed a similar pattern, cases occurring primarily at the end of the working week and mostly over the week-end. We are unable to explain this. One would have thought that the development of cases would have coincided with the delivery and handling of infected birds. This, however, does not appear to be so. We can only suggest that in order to produce an outbreak there must be a minimum effective dose of infecting material, and this, owing to the gradual concentration over the week during its passage through the plant, is more likely to develop at the end rather than at the beginning of the week.

Until August 1962 vaccination was prohibited and the Ministry of Agriculture's policy was compulsory slaughter of all flocks in which Newcastle disease was found. Obviously until this time the source of infection was birds in which subclinical or carrier state of the Newcastle disease existed. These flocks would escape compulsory slaughter at the farm and be received at the packing-station. Judging by the sporadic cases in late 1962 and during 1963 the Newcastle disease virus was still present among certain flocks, and the last outbreak investigated in late December 1963 and early January 1964 showed that clinical cases of the disease were present among chickens at one of the supply farms. Since January 1964 there has been no further outbreak of conjunctivitis among workers at the three broiler factories, which might indicate that the programme of vaccination is now controlling the disease at chicken farms.

Some of the conjunctival washings were inoculated on to monkey kidney and HeLa cells ; the results were not very clearcut and no haemadsorption was detected. Isolation of the virus by means of fertile eggs was so successful that tissue culture was abandoned.

The virus isolation rate does not seem very high, far less than $100 \%$. This might be expected, because (a) only one specimen was taken from each patient on only one occasion; $(b)$ only one egg was inoculated from each specimen; and $(c)$ blind passage of negative allantoic fluids was not carried out.

If more specimens and more eggs were used in carrying out blind passage it would be reasonable to expect a greater number of isolations. There is some support for this statement in that when two cases of conjunctivitis in poultry-farmers were examined by means of two specimens from each and with more that one egg per specimen Newcastle disease virus was isolated from both.

\section{Summary}

Several outbreaks of conjunctivitis among workers in chickenbroiler factories are described. The broiler factories were three in number, belonging to the same company but situated many miles from each other. The outbreaks at all three factories at all times followed a similar pattern.

Though Newcastle virus was suspected from the initial outbreak in December 1960, it was not possible-in spite of several 
attempts-to isolate the Newcastle disease virus until an outbreak in factory B in December 1963.

An infective agent as a causal factor was again obscured by the absence of outbreaks of fowl pest among the chickens handled. The final method used in the isolation and identification of the Newcastle disease virus is described.

We wish to thank Dr. N. S. Galbraith, of the Epidemiology Reference Laboratory, Colindale, and Dr. G. F. Smith, H.M. Medical Inspector of Factories, South-western Division, for their helpful comments following their investigations of an outbreak at Factory C ; Dr. G. T. Cook, Director of the Public Health Laboratory, Guildford, for his help during the initial outbreak at Factory A ; Dr. T. D. Blott, Medical Officer of Health, Chelmsford and Maldon U.D.C., for his most helpful co-operation during the investigation of outbreaks at Factory B ; and Miss Barbara Wall, F.I.M.L.T., for technical assistance.
Finally, we should like to thank the management, who were always most helpful and co-operative throughout the investigation.

REFERENCES

Anderson, S. G. (1946). Med. F. Aust., 1, 371

Burnet, F. M. (1943). Ibid., 2, 313.

Doyle, T. M. (1927). f. comp. Path., 40, 144.

Freymann, M. W., and Bang, F. B. (1949). Bull. Fohns Hopk. Hosp., 84, 409.

Gustafson, D. P., and Moses, H. E. (1951). 7. Amer. vet. med. Ass., 118, 1 .

Hunter, M. C., Keeney, A. H., and Sigel, M. M. (1951). F. infect. Dis.,

Ingalls, W. L., and Mahoney, A. (1949). Amer. F. publ. Hlth, 39, 731. Nelson, C. B., Pomeroy, B. S., Schrall, K., Park, W. E., and Lindemann

Pilsworth, R., and Wall, Barbara J. (1964). Mth. Bull. Minist. Hlth Serv., 23, 122 .

Yatom, J. (1946). Refuah. Vet., 3, 69.

\title{
Helminth Infestations in Immigrant Children
}

\author{
D. M. ARCHER,* B.SC.; F. N. BAMFORD, † M.B., CH.B., D.C.H., D.P.H. ; E. LEES, $\ddagger$ B.SC., PH.D.
}

Brit. med. F., 1965, 2, 1517-1519

During the past decade the city of Bradford has become the home of about 12,000 Commonwealth immigrants. At first the majority of newcomers were men who worked to support families they had left behind in Pakistan and India, but recently an increasing number have been joined by their wives and children. In January 1965 it was decided to invite all immigrants to have their children medically examined before admission to school. In addition to a general physical examination and an educational assessment, haemoglobin estimation, tuberculin-testing, and examination of the stools for pathogens and ova were done for each child. Subsequently a similar form of examination was carried out on all children of immigrant origin who had previously been admitted to our schools.

This paper is concerned with the results of our examination for the ova of intestinal parasites. We were principally interested in three questions: first, the rate and type of infestation of children from different parts of the Commonwealth; secondly, the possibility of cross-infestation in this country; and, thirdly, the effect of a period of residence in this country on infestation rates.

Altogether 419 immigrant children applying for admission to school between 1 January and 1 June 1965 and 898 already in schools were examined. The results include $100 \%$ of children arriving in Bradford, the parents, without exception, agreeing to the examination.

\section{Method}

Each child was given a small screw-cap bottle and spatula and was asked to bring a fresh stool sample to the examination. Bacteriological examination was done on the day of receipt, $5-10 \%$ formalin solution was added to the bottle, and the examination for ova was completed within a week of receipt.

The examination for helminth eggs involved a single "direct smear," a small quantity of faeces being emulsified in a drop

\footnotetext{
* Lecturer in Zoology, Institute of Advanced Technology, Bradford. $\dagger$ Principal Medical Officer in Child Health, Bradford.

$\mp$ Professor
}

\section{Results}

Five types of ova were detected in the samples: they were hookworm (Ancylostoma duodenale and/or Necator americanus), whipworm (Trichuris trichiura), roundworm (Ascaris lumbricoides), dwarf tapeworm (Hymenolepis nana), and beef tapeworm (Taenia saginata).

The total incidence is shown in Table $I$. The types of multiple infestations found are given in Table II. The rates of infestation according to area of origin are given in Table III. The effects of age and sex are shown in Figs. 1-3.

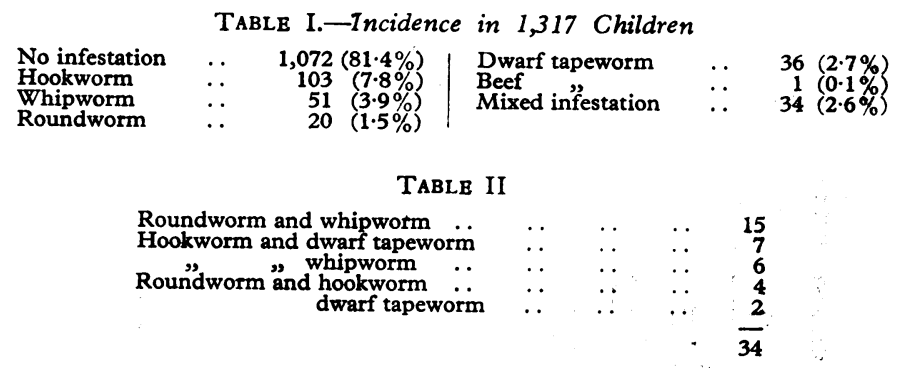

Cross-infestation in the United Kingdom.-The following infestations were found in children born in the United Kingdom to immigrant parents.

Case 1.-A boy aged 6 of Indian parents had a dwarf-tapeworm infestation. He had never left the United Kingdom.

Case 2.-A girl aged 5 of Indian parents had a roundworm infestation. She had never left the United Kingdom.

Case 3.-A boy aged 5 of West Indian parents had a hookworm infestation. He had never left the United Kingdom.

Cases 4-6.-Two boys and a girl of West Indian parents each had a whipworm infestation. They had all visited the West Indies four and five years previously.

Case 7.-A boy aged 6 of Pakistani father and European mother had a mixed infestation with roundworm and whipworm. He had stayed in Pakistan for six months in 1963.

Effect of Residence in Great Britain.-The incidence of infestation in children who arrived in this country in different years is shown in Figs. 4 and 5 . Those in whom the year of arrival was uncertain have been excluded from these results. 